\title{
RESCUING THE LM (and the money market) IN A MODERN MACRO COURSE
}

Roberto Tamborini 
The Discussion Paper series provides a means for circulating preliminary research results by staff of or visitors to the Department. Its purpose is to stimulate discussion prior to the publication of papers.

Requests for copies of Discussion Papers and address changes should be sent to:

Dott. Stefano Comino

Dipartimento di Economia

Università degli Studi

Via Inama 5

38100 TRENTO ITALIA 


\title{
Rescuing the LM (and the money market) in a modern Macro course
}

\author{
Roberto Tamborini \\ University of Trento, Department of Economics, \\ Via Inama 5, 38100 Trento, Italy, \\ roberto.tamborini@economia.unitn.it
}

March 2007

\begin{abstract}
This paper considers recent proposals of introductory-level macroeconomic models that drop the LM apparatus in favour of the straightforward use of the Taylor rule as a means to determine the nominal interest rate and to link the monetary block with the real block of the economy. Whilst one can only agree with the various complaints made against the traditional treatment of the LM apparatus that still survives in modern textbooks, the new IS-AS-TR workhorse has several drawbacks as well, the most serious one being that it completely hides the concept of monetary equilibrium from view, transmitting the faulty idea that the central bank can set the (real!) interest rate at will, with no connection at all with money demand and supply. The paper suggest how a Macro course could be structured around a model of New Keynesian inspiration where the LM block is amended rather than suppressed. Section 2 surveys the foundations of the macro-model. Section 3 deals with the foundations of the role of money in the model, and shows how to derive a consistent LM "gap function" in relation to "output gaps" and "inflation gaps" according to current practice. Section 4 expands upon the monetary block, highlighting that it admits of two monetary policy regimes, the "exogenous-money regime", and the "endogenous-money regime". The latter leads quite naturally to the Taylor rule, while making it clear that this is a particular choice of the central bank, and that it implies an endogenous path of the money stock determined by the underlying money market equilibrium. Section 5 concludes.
\end{abstract}





\section{Introduction}

The diffusion of direct control of the interest rate among central banks, and the parallel development of consensus on the so-called "New Neoclassical Synthesis" blending New Classical and New Keynesian insights (Goodfriend and King (1997), Blanchard (2000), Woodford (2003)), have paved the way for the idea that macro-modelling can benefit greatly if it starts directly from the "fundamental three equations" consisting of aggregate demand (IS), aggregate supply (AS) and a Taylor rule (TR) representative of interest-rate-based monetary policy. Taylor (2000), Romer (2000), Allssop and Vines (2000), Carlin and Soskice (2004) provide examples of introductory-level treatments. Aside from the theoretical innovations in the aggregate demand and supply functions (which can be introduced at higher levels of sophistication), the main difference between this new workhorse and the one on duty to date (generally known as IS-ASLM) is that the TR replaces the LM function as a means to determine the nominal interest rate and to link the monetary block with the real block of the economy.

As argued by Romer (2000), dispensing with the LM apparatus altogether has several advantages. First, in its traditional static version the LM is notoriously faulty in various respects (see also Leijonhufvud (1983) for early warnings): to mention only a few, 1) the LM is derived from money stock equilibrium while being embedded in a flow equilibrium setup, 2) when the real money stock is made explicit as the determinant of the LM schedule, the relevant variable is the general price level (GPL) whereas the key variable in the macroeconomic debate is the inflation rate. Second, from the point of view of monetary policy, the LM implies that the central bank controls the level of the money stock in the economy, whereas today the general practice of central banking is based on direct control of interest rates. By contrast, starting from scratch with output, inflation and the interest rate, as with the TR, is quite attractive and may ease the transition of students from the economics of the press to the economics of the 
classroom. As Romer himself notes, however, the diffusion of the IS-AS-TR model in textbooks is rather slow, much slower than one might expect from its academic dominance.

One reason may be that, as is often the case, the change of workhorse does not have advantages alone. There are also drawbacks. B. Friedman (2003) has pointed some of them out. In his view, a major defect on the side of the bare IS-AS-TR framework is that it completely hides the concept of monetary equilibrium from view, transmitting the faulty idea that the central bank can set the interest rate at will, with no connection at all with money demand and supply. ${ }^{1}$ This idea is blatantly at variance with the claim that modern macroeconomics should be taught as a discipline firmly rooted in the general-equilibrium principles. It may be added that, at the same time, this representation of the monetary sector conveys the equally faulty idea that, were the central bank to remain passive, the interest rate would be totally unrelated to changing states in the economy such as, say, an increase in inflation or in output. No less problematic is the hazardous shortcut taken by Romer (2000) and Taylor (2000), who posit that the central bank directly sets the real interest rate. This seems hardly viable as a solution to the problem that the old IS-LM system failed to distinguish between nominal and real interest rate owing to the missing link of expected inflation.

These are serious problems, for they do not concern the unavoidable pros and cons of simplifying assumptions and their right dosages, but rather fundamental points of conceptual consistency that may distort the learner's conception of the macroeconomy. As a personal example of someone who teaches macroeconomics on a finance curriculum, the disappearance of the LM apparatus would make it hard for students to recollect the macroeconomic role of the credit and asset markets that they study in separate courses. On the other hand, one can only agree with Romer's remarks against the traditional treatment of the LM apparatus that still survives even in modern textbooks.

Ideally, we would like to have a basic macroeconomic model that conveys clear and theoretically consistent ideas about the relationships

\footnotetext{
${ }^{1}$ Indeed, Woodford, in his major and influential treatise (2003), argues that the ISAS-TR model can be conceived as being totally independent of the existence of money.
} 
among monetary policy, nominal interest rate, output and inflation in the context of short run business cycles by amending the LM block rather than suppressing it. This is the aim of this paper. It may be read as a guide to structuring a Macro course around a basic New Keynesian model, although its main focus is restricted to the monetary block of the economy. Section 2 overviews the foundations of the macro-model. It provides the background for the treatment of the monetary block subsequently expounded, and introduces the $\mathrm{AD}$ and $\mathrm{AS}$ functions in a form that, according to current practice, relates "output gaps" to "inflation gaps" with respect to generalequilibrium trend values. Section 3 deals with the foundations of the role of money in the model, and shows how to derive a consistent LM "gap function" in relation to output gaps and inflation gaps. Section 4 expands upon the monetary block, highlighting that it admits of two monetary policy regimes, the "exogenous-money regime" where the central bank controls the rate of growth of the money stock, and the "endogenous-money regime" where the central bank sets the nominal interest rate. The latter leads quite naturally to the Taylor rule, while making it clear that this is a particular choice of the central bank, and that it implies an endogenous path of the money stock determined by the underlying money market equilibrium. It can therefore be seen that, when properly re-worked in an inflationary setup, the LM apparatus has no faults, and that the exogenous and endogenous monetary regimes are formally equivalent because they are both consistent with monetary equilibrium. Section 5 concludes.

\section{Overview of the macroeconomic model}

This section summarizes the building blocks of a simple macroeconomic model of New Keynesian inspiration providing the basic elements for understanding business cycles, that is to say, short-run fluctuations of output and inflation. The introductory elements presented in this section provide the background for the treatment of the monetary block set out subsequently.

\subsection{Basic ideas and facts}

The approach considered here rests on the idea that output fluctuations occur around a given growth trend, and that the two phenomena are produced by sets of causes that can be analysed separately. 
Though this idea has been criticised by important scholars and different schools of thought, both past (e.g. Keynes (1937)) and present (e.g. the "Real Business Cycle" school introduced by, among others, Lucas (1977)), today it is nonetheless part of the "new consensus" in macroeconomics, which is also known as the "New Neoclassical Synthesis" (e.g. Blanchard (2000)).

The economy is "on the trend" when all markets clear and all agents' plans are realized and mutually consistent. In other words, points in time on the trend correspond to the economy being in general equilibrium. The corresponding measure of output is called "potential output". It should be stressed that modern theory distinguishes different types of equilibrium, and different levels of potential output, depending on the working of factors as well as goods markets. If all markets are perfectly competitive and with no "frictions", or more generally if they obey the Walrasian paradigm, then potential output takes the highest possible level corresponding to Pareto efficient allocations in the economy. If any market deviates from perfect competition (e.g. firms have some degree of monopoly power in the output market, or workers have it in the labour market, etc.), the economy will suffer a loss of potential output failing to achieve Pareto efficiency. Generally speaking, these inefficiencies are rubricated as "real rigidities".

In this connection, of particular importance is the idea of "natural rate of unemployment", or else "structural unemployment", introduced into modern macroeconomics by Friedman (1968) and Phelps $(1968,1970)$. Since then, this idea has received innumerable refinements and developments (and criticisms) in various directions. Their common, stylized features, are twofold: 1) firms and workers are cast in a non-Walrasian environment in which they bargain over the contractual real wage; 2) as a result, in equilibrium, the latter is generally set above the full-employment real wage. ${ }^{2}$

These imperfections notwithstanding, potential output, being the result of optimal responses by agents to the given market conditions and signals, remains the best possible outcome for the economy, and corresponds

2 An alternative approach concentrates the "frictions" in the output market, typically in the form of monopolistic competition over differentiated goods (Blanchard and Kiyotaki (1987)). As is well-known from first principles, profitmaximizing monopolistic pricing entails that the demand price for labour exceeds the competitive one in proportion to the optimal mark-up. Hence the result on the labour market is again that the real wage is set above its full-employment value. 
to the general equilibrium of markets, under the given conditions and constraints.

The development of the concept of potential output has led all major official statistical agencies to provide estimated time series of it, which may be used to show that potential output itself may be subject to shocks (the time trend is not linear). Yet, in accordance with the idea of fluctuations set forth at the beginning, the data show further deviations of actual output from its potential level at any point in time. ${ }^{3}$ The rate of deviation of actual output $Y_{t}$ from potential output $Y^{*}{ }_{t}$ at each point in time $t$ is usually called "output gap" (i.e. $\hat{Y}_{t}=Y_{t} / Y^{*}{ }_{t}-1$ ). For our present purposes we shall ignore shocks to potential output, and in particular, we shall assume that it is constant (the trend growth rate is nil), $Y^{*}=Y^{*}$ all $t$. As regards output gaps, the key idea is that these occur because of inefficient responses of markets to shocks, in particular as regards the missing adjustment of the nominal prices of factors or goods to new market conditions. These other "frictions" are also known as "nominal rigidities"4.

Like output, also the general price level (GPL) typically increases over time at an uneven pace, so that it, too, can be decomposed into fluctuations and the underlying trend. As long as the GPL is on the trend, prices are growing at the historical inflation rate. Whenever the GPL is

3 It may be added that, over the short time horizon appropriate to the observed frequency and amplitude of fluctuations, the assumption that the autonomous determinants of the growth trend of output are substantially invariant, so that they can be taken as given exogenously, may be accepted as realistic. Or to put it differently, there is no sufficient evidence that the determinants of growth may change with the frequency and amplitude necessary to fit those of the actual business cycles in major industrial economies (Mankiw (1989)). More problematic is the objection that fluctuations themselves may react back onto the determinants of growth (e.g. a slump may shift the economy onto a lower growth path). This possibility is simply ruled out by the way in which the efficient level of output - i.e. the level of output that lies on the trend at each point in time - is obtained in the model (see below).

4 The combination of real and nominal rigidities is an important feature of the theory. In fact, if there were no real rigidities and the economy reached the Paretoefficient frontier, we should only observe fluctuations in prices, not in quantities (unless the determinants of potential output fluctuate on their own). The phenomenon of output fluctuations above potential is only conceivable if, when the economy is on the trend, there remains a reserve of unused resources that can be activated under particular circumstances. 
above (below) the trend, prices are growing faster (slower) than the historical inflation rate.

Macroeconomic principles have long been taught with reference to the GPL: it is common to read in textbooks that as a result of an increase (reduction) of aggregate demand the GPL rises (falls). This practice is somewhat confusing to ordinary people, who have no experience of falling absolute prices (as a matter of fact, this is a rare phenomenon that may occur in connection with severe general economic crises). If one wants to stick to the tradition, then the correct concept is that the GPL $P_{t}$, at a given point in time $t$, may rise above (or fall below) its trend value $P^{*}$ at that point in time. Yet, the inflation rate, not the absolute GPL, is at the center of the attention of central banks, as well as of governments, economists and public opinion. Hence, it seems recommendable that the inflation rate is introduced into the picture from the outset.

Moving from the absolute values of the GPL to inflation rates, the time series of the latter can still be interpreted as deviations from the trend traced by the historical inflation rate. In fact, defining the actual inflation rate as $\pi_{t} \equiv\left(P_{t} / P_{t-1}\right)-1$, and the historical rate as $\pi^{*}{ }_{t} \equiv\left(P^{*}{ }_{t} / P^{*}{ }_{t-1}\right)-1$, it

follows that, starting from the GPL being on the trend, $P_{t-1}=P_{t-1}^{*}$, excess inflation $\pi_{t}>\pi^{*}{ }_{t}$ corresponds to the GPL being above the trend $P_{t}>P^{*}{ }_{t}$ and vice versa.

\subsection{Agents and markets}

Since modern macroeconomics prescribes general-equilibrium thinking, it should be clarified that the model at hand is built upon a basic general-equilibrium scheme that can be sketched as follows. The economy hosts two classes of private agents: households and firms. The only public policy maker is the central bank. Households own productive human capital, supply this factor to firms at the market wage rate, consume and save. Firms are technical units that transform inputs of human and physical capital into output, which is a single homogenous good that can either be consumed by households or invested by firms themselves as additional physical capital. In order to invest, firms have to borrow out of households' savings at the market interest rate. Consequently, three markets operate in this economy: the two factor markets, labour and (financial) capital, and the output market. All transactions take place by means of fiat money issued 
by the central bank, and therefore all the prices of factors and output are denominated in money units.

The latter is an important feature of the economy for two reasons. First, it introduces fiat money as a means of payment. Fiat money is not a spontaneous creation of markets, but an institutional artefact, enforced by public authorities, aimed at fostering market efficiency. A large microeconomic literature offers a variety of explanations for this artefact, whose common trait is the correction of a third class of market "frictions" that can be traced back to the broad concept of "transaction costs" (e.g. Goodhart (1989), Walsh (2003)) Second, the fact that in a monetary economy all prices are denominated in money units (in order to economize on transaction costs), paves the way for treatment of the main cause of output fluctuations in this theory, namely nominal rigidities. In this respect one may find various treatments, focusing on different markets (typically labour and/or goods markets), and at different levels of complexity (e.g. Mankiw and Romer (1991)). A simple and consistent introduction to the issue starts from the observed fact that transactions, especially in factor markets, largely (though not exclusively) take place by means of long-term contracts, that

- determine the obligations in nominal terms that are usually (though not systematically) not indexed to the GPL, and

- are not revised until expiration.

Hence, our characterization of the labour market is that workers and firms periodically subscribe to a new labour contract that

- determines the nominal wage rate per hour worked against the number of hours worked, and

- is valid for at least 1 period of time with no recontracting. 5

It is evident that this rather common arrangement in labour market relations introduces a form of nominal rigidity into the economy. In fact, let $W_{t-1}$ be the nominal wage rate set in $t-1$ for the contract ruling in $t$. If workers and firms do not suffer from "money illusion", they set $W_{t-1}$ by bargaining over a contractual real wage rate $\underline{W}_{t}^{c}$ augmented for the expected GPL in period $t$, i.e.:

5 This is a simplified version of the model of "staggered wage contracts" put forward by Taylor (1980) and which gives rise to a particular form of nominal rigidity that will be discussed below. 


$$
W_{t-1}=\underline{W}_{t}{ }_{t} P_{t}
$$

This fact has the major consequence that the actual real wage rate for period $t$ is given by $\underline{W}_{t}=W_{t-1} / P_{t}=\underline{W} c_{t} P^{e}{ }_{t} / P_{t}$. In other words, once the labour contract for period $t$ is in force, firms and workers may face a value of $\underline{W}_{t}$ that is higher (lower) than $\underline{W}^{c}$. This effect, also known as "price surprise effect", occurs whenever $P_{t}$ is lower (higher) than expected. On the other hand, the price surprise effect hits the real wage rate to the extent that the nominal rate is not immediately adjusted to the actual GPL. In this sense, there is a nominal rigidity in the economy. More precisely, however, the situation is one of imperfect indexation due to two concomitant circumstances: 1) a fixed-length contract, 2) imperfect foresight (number 1 would be harmless with perfect foresight of the future GPL; number 2 would be harmless as well if continuous recontracting were possible). Whereas the hypothesis of imperfect foresight needs no particular justification in the real world, fixed-length contracts raise the objection that rational agents (who know that their forecasts are fallible) may not wish to accept these contracts. However, they are widely used in market transactions, and a possible explanation put forward by the literature is that recontracting is costly: as a result, fixed-length contracts are accepted as long as probable losses do not exceed recontracting costs. ${ }^{6}$

Likewise, the capital market trades corporate bonds that

- determine the nominal interest rate per money unit of loan, and

- are valid forever with no recontracting (unless the issuing firm is foreclosed; note that the individual holder can still "recontract" by selling the bond).

\subsection{Aggregate supply and inflation}

Aggregate supply (AS) is the rate of production that profitmaximizing firms are ready to offer upon employing their optimal inputs of physical and human capital, given the production function that relates output with these inputs.

\footnotetext{
6 This explanation is consistent with the evidence that long term contracts are widespread in economies with low or moderate inflation. Fast growing and unstable prices induce agents to introduce automatic indexation clauses (this was for instance the case in Italy in the 1970s) or destroy any form of commitment altogether (Hymann and Leijonhufvud (1995)).
} 
The standard properties of the production function are those of constant returns to scale and decreasing marginal productivity of factors. It is convenient to add that labour is the more readily variable factor (it can be immediately adjusted vis-à-vis current market conditions), whereas existing capital is the fixed factor (existing capital takes 1 period of time to wear out, new capital takes 1 period of time to become operative). The most convenient representation of these technical data is the Cobb-Douglas production function

$$
Q_{t}=T K_{t}^{(1-\alpha)} N_{t}^{\alpha}
$$

where $T$ stands for "technology" affecting total factors productivity, $K_{t}$ is the stock of physical capital available for period $t, N_{t}$ is labour (hours worked) employed in period $t$.

Profit maximization requires that firms pay factors the value of their marginal product at the current sale price, under the budget constraint

$$
P_{t} Q_{t}=W_{t-1} N_{t}+R_{t-1} P_{t-1} K_{t}
$$

This budget constraint (which in aggregate is the national income identity) arises from the fact that firms are committed to paying workers the contractual nominal wage rate $W_{t-1}$ established one period earlier, and are committed to paying savers the contractual nominal (gross) interest rate $R_{t \text { - }}$ ${ }_{1}$ on the amount of physical capital operating in $t$ that has been purchased one period earlier by borrowing from savers the relevant amount of funds. Note that by deflating the budget constraint by $P_{t}$ we have, in real terms,

$$
Q_{t}=\underline{W}_{t} N_{t}+\underline{R}_{t} K_{t}
$$

where $\underline{W}_{t}=W_{t-1} / P_{t}$ is the current real wage rate, and $\underline{R}_{t}=R_{t-1} P_{t-1} / P_{t}=$ $R_{t-1} /\left(1+\pi_{t}\right)$ is the actual real interest rate in period $t$ on bonds issued in $t-1$.

A production function like the Cobb-Douglas, and the real budget constraint, imply that if $\underline{R}_{t}$ is to equate the marginal product of capital, then $N_{t}$ should be set to equate the marginal product of labour with $\underline{W}_{t}$. Since $K_{t}$ is fixed, while $N_{t}$ is variable, firms are allowed to optimize their factors mix by adjusting $N_{t}$ in the course of period $t$ as they observe $P_{t}$, given $W_{t-1}$. The consequent expression for AS can conveniently be derived in loglinear terms from the Cobb-Douglas function, that is,

$$
y_{t}^{s}=-y_{w}\left(\underline{w}^{c}+\left(p^{e}{ }_{t}-p_{t}\right)\right)+u_{t}^{s}
$$

where small-case letters indicate logs of capital-case variables, and $u_{t}^{s}=$ $\tau /(1-\alpha)+k_{t}, y_{w}=\alpha /(1-\alpha)$.

Consequently, we can see that employment and $A S$ are sensitive to price forecast errors, and they increase (decrease) as $p_{t}>p^{e}{ }_{t}\left(p_{t}<p^{e}{ }_{t}\right)$. This 
component of aggregate supply is only due to the imperfect indexation of the nominal wage rate. Conversely, we can ask what the level of AS is when there are no forecast errors (or equivalently with perfect indexation of the nominal wage rate), i.e.

$$
y^{*}{ }_{t}=-y_{w} \underline{w}^{c}{ }_{t}+u^{s}{ }_{t}
$$

This level of AS is uniquely determined by the real, or structural, variables and parameters, and it corresponds to the definition of potential output. As recalled above, the level of $y^{*}{ }_{t}$ will in turn correspond to Pareto efficiency and full employment depending on whether $\underline{w}_{t}^{c}$ clears the labour market at full employment or not.

The expression of the output gap is then easily obtained as a function of price forecast errors, in fact in logs,

$$
\hat{y}_{t}^{s} \equiv y^{s}{ }_{t}-y^{*}{ }_{t}=y_{w}\left(p_{t}-p^{e}{ }_{t}\right)+\hat{u}^{s}{ }_{t}
$$

We are now in a position to understand the difference between the economy being on the trend or off the trend. On the trend we know that all nominal prices grow at the constant rate $\pi^{*}$, and $\hat{u}_{t}{ }_{t}=0$ Therefore, at each bargaining round, say at $t$ - 1 , firms and workers revise the (log of the) nominal wage rate according to

$$
w_{t-1}-w_{t-2} \equiv \hat{w}_{t-1}=\underline{\hat{w}}_{t}^{c}+\pi^{*}
$$

Unless a specific shock hits the labour market, we can set $\underline{\hat{w}}_{t}^{c}=0$. Hence potential output remains constant, too, at $y^{*}$, while the nominal wage rate grows at the rate $\pi^{*}$. As long as the GPL does grow at the rate $\pi^{*}$, there are no price forecast errors and no output gaps: anticipated inflation is neutral on aggregate supply. By contrast, as soon as the economy deviates from the trend and $\pi_{t}$ differs from $\pi^{*}$, we can see that

$$
\hat{y}_{t}^{s}=y_{w}\left(\pi_{t}-\pi^{*}\right)
$$

that is to say: output gaps are a function of unanticipated inflation or "inflation gaps".

\subsection{Aggregate demand and inflation}

Aggregate demand (AD) is the sum of consumption $C_{t}$ and investment $I_{t}$ in each period $t$. Each component can be studied separately at various levels of complexity. In traditional Keynesian macroeconomics they were represented as strongly related to two main different determinants, namely current disposable income for consumption, and the current real interest rate for investment. In the Hicksian representation, these relationships 
were collapsed in the IS locus, that is to say, the combinations of income and interest rate, such that

$$
S_{t}=Y_{t}-C_{t}\left(Y_{t}, \bullet\right)=I_{t}\left(r_{t}, \bullet\right)
$$

The long and deep micro-foundational work of the last decades has led to quite a different treatment. First, the new consumption theories based on Modigliani's life cycle hypothesis (1954) and Friedman's permanent income hypothesis (1957) tend to downplay the dependence of consumption on current disposable income and to focus on the intertemporal determinants of households' plans where the interest rate is deemed the crucial variable. Second, developments in investment theory based on explicit firms' intertemporal optimization give prominence to the forwardlooking real interest rate either directly or via "Tobin's $q$ " model (1969). One way or another, these models of consumption and investment may be synthetized in simple log-linear AD functions like the following

$$
y_{t}^{d_{t}}=-y_{r}\left(r_{t}-\pi^{e}{ }_{t+1}\right)+u^{d}
$$

where the only relevant variable is the expected real interest rate, while $u_{t}{ }_{t}$ captures exogenous real determinants (typically future expected incomes or Friedman's permanent income).

Note that this representation of $\mathrm{AD}$ is consistent with our accounting and decision-making framework. In fact, $\left(r_{t}-\pi^{e}{ }_{t+1}\right)$ is relevant to investing firms and saving households as it measures the real return on bonds that firms are expected to pay to savers when purchases of capital at time $t$ will become operative at time $t+1$. In fact, the sign of the coefficient $y_{r}$ indicates that when $\left(r_{t}-\pi_{t+1}^{e}\right)$ increases $\mathrm{AD}$ decreases because firms wish to invest less and households wish to consume less to save more.

Note, also, that as a consequence the current practice to label equations like (4) with the Hicksian acronym IS is inappropriate and misleading. These are not investment=saving $(\mathrm{AD}=\mathrm{AS})$ loci; they are consumption+investment functions, and in some important models, investment is absent altogether (e.g. McCallum and Nelson (1999), Woodford (2003), ch. 4).

$\mathrm{As}$ in the case of $\mathrm{AS}$, we can distinguish between $\mathrm{AD}$ when the economy is on the trend and when it is not. In the former case, the GPL grows (and agents expect it to grow) at the constant rate $\pi^{*}$. Moreover, the economy produces the constant rate of potential supply $y^{*}$. Therefore, according to equation (4),

$$
y^{*}=-y_{r}\left(r_{t}-\pi^{*}\right)+u_{t}^{d}
$$


Clearly, the AD-AS equilibrium at potential output and constant inflation rate implies a related value of the real interest rate,

$$
\underline{r}^{*}=\left(u^{d}-y^{*}\right) / y_{r}
$$

This may be called the "natural interest rate" (Woodford (2003), in homage to Knut Wicksell (1898) who first introduced this notion), and it is constant unless the exogenous components of $\mathrm{AD}\left(u^{d}\right)$ or $\mathrm{AS}\left(y^{*}\right)$ are shocked.

The modern interpretation of this "natural" value of the real interest rate is that it is part of the real determinants of the general equilibrium of the economy, and that it therefore provides (or should provide) the reference value, or the "anchor", for the nominal interest rate $r_{t}$ at any point in time $t$. In nominal terms, this requirement can be written as $r^{*}=\underline{r}^{*}+\pi^{*}$, which is called the "neutral interest rate" or NAIRI (non-accelerating-inflation rate of interest) (e.g. Blinder (1998)). In fact, suppose that $r_{t} \neq r^{*}$ : it is easy to see that $\mathrm{AD}$ in period $t$ deviates from $y^{*}$ by the amount

$$
\hat{y}_{t}^{d} \equiv y_{t}^{d}-y^{*}=-y_{r}\left(r_{t}-r^{*}\right)+\hat{u}^{d}{ }_{t}
$$

As a result, we have a "gap equation" for $\mathrm{AD}$, analogous to the "gap equation" for AS, which provides a basic theory of out-of-trend movements of output. These are traced back to "interest rate gaps", that is, deviations of the nominal interest rate from the NAIRI. Positive (negative) interest rate gaps feed downward (upward) shifts of AD. For the economy to produce less (more) output, $\hat{y}_{t}^{s}=\hat{y}_{t}^{d}$, the current inflation rate should fall (rise) with respect to $\pi^{*}$ :

$$
\left(\pi_{t}-\pi^{*}\right)=-\frac{y_{r}}{y_{w}}\left(r_{t}-r^{*}\right)
$$

Consequently,

- inflation fluctuations (inflation gaps) are inversely related to interest rate gaps

- the inflation rate is stable as long as the nominal interest rate equals the NAIRI

Interest rate gaps in turn may be due either to non-accommodated shocks in the real $\left(\underline{r}^{*}\right)$ or nominal $\left(\pi^{*}\right)$ component of the NAIRI itself, or to autonomous changes in $r_{t}$. In either case, a complete analysis of $\mathrm{AD}$ fluctuations requires modelling the determination of the nominal interest rate. Moreover, the reader may have noted that the $\mathrm{AD}$ gap equation (6), unlike the AS gap equation (4), does not include the current inflation rate $\pi_{t}$. On closer inspection, that neither consumption nor investment react to accelerating or decelerating inflation may strain credibility. As we shall see, 
this point, too, may be accommodated by appropriate determination of the nominal interest rate.

Before leaving this outline of the macro-model, the reader may raise the legitimate question why the trend inflation rate is what it is. Indeed, so far we have just assumed that the rate $\pi^{*}$ is given exogenously. Does this model determine this rate? The theoretical answer is no. More precisely, the set of determinants of potential output, and of the associated general equilibrium of markets, leave the GPL at any point in time indeterminate. This is the essence of a fundamental principle of general equilibrium theory, that is, Say's Law.

To grasp this principle, in the first place it should be noted that none of the determinants of potential output (technology, preferences, production factors, real interest rate, real wage rate, etc.) depends on the GPL or its growth rate. Even though factor incomes are denominated in money units, it has been assumed that rational agents are free from "money illusion", that is, they bargain over real incomes and index their nominal values to the inflation rate. Thus, we have seen, the latter is neutral on real allocations. In the second place, general-equilibrium accounting implies that the value of output is equal to the value of factor incomes, which in turn are allocated to purchases of produced goods. It follows that if factor incomes are split between consumption and saving, and output consists of consumption and capital goods, then saving must equal the value of purchases of capital goods, that is, investment. Therefore, the real interest rate associated with demand-supply equilibrium in the goods market (equation (5)) implies saving-investment equilibrium in the capital market, and the goods market always clears for any amount of potential output. In other words, because of Say's Law, "supply creates its own demand" for any (indeterminate) GPL.

It is of some intellectual interest to observe that, whereas modern theory dictates that macroeconomic relationships should be rigorously derived from microeconomic rational behaviour, Say's Law, which is one of its central tenets, is a purely macroeconomic law that has no counterpart at the level of single markets. At this level, one is taught that there is a single price at which supply can be absorbed by demand. To resume this basic principle at the macro-level, where we deal with one single (composite) good and one single (composite) price, Say's Law should be dropped. This was in fact the central argument put forward by Keynes (1937b) in his effort to devise an entirely new theory of business cycles. The reason why, according 
to Keynes, Say's Law does not apply - "the monetary nature of the interest rate" - has then been transfused into the standard treatment of macroeconomic principles, and will be reconsidered below. Others, notably Patinkin (1965), have offered different explanations - such as "real money balances in the demand function" - that have also been systematized in the development of modern macroeconomic theory. For the time being, it suffices to point out the common theme of these variations: to obtain a determinate GPL, demand should depend on the GPL in a way that makes it independent of supply.

\section{Money and the nominal interest rate}

In the previous section it was stressed that a key feature of the economy is that all transactions take place by means of fiat money issued by the central bank. It was also recalled that this is fundamentally an institutional artefact that fosters market efficiency by reducing the severe transactions costs (time waste for search of double coincidence of wants, carry and storage costs of "barter goods", huge increase of informational requirements regarding "real" relative prices, etc.) that would arise in the absence of a general means of payment. ${ }^{7}$ One of the permanent achievements of the "Keynesian Revolution" in modern macroeconomics is that a monetary economy is not just a "barter economy" with "the veil of money" (Hahn (1982)). A consistent representation of a monetary economy should start with money being rationally understood and managed by individual agents. As a consequence, the presence of money should change agents' decisions and market allocations with respect to an economy with no need for money. In the previous section we took a first step in this direction by showing the implications of goods and production factors being denominated in money units. In this section we shall examine the implications of agents' direct management of money.

\subsection{The role of money in the economy}

7 Beseide theory, hyperinflations are historical experiments showing the serious damage that market economies suffer from the disappearence of fiat money: see e.g. Heymann and Leijonhufvud (1995). 
The Keynesian legacy in modern monetary macroeconomics lies in the general proposition that money serves two fundamental purposes in the economy: means of payment and store of value. Yet it is seldom clarified that these two functions are not separable; they cannot be analyzed or modelled as if they were independent. If agents benefit from using money as a means of payment for their current transactions, they must also benefit from holding money as a store of value for their future transactions. This twofold aspect of money can be grasped by observing the sheer fact that any monetary transaction consists of exchanging a good or service for money: one of the two parties in exchange ends up with a money balance. To accept this, he/she should also be confident that his/her money balance will be accepted in exchange for goods and services in future transactions. This is a rational belief to the extent that the currency of denomination of money balances maintains its status of general means of payment and that money balances can be carried over time efficiently. Therefore monetary transactions are feasible over time as long as money is an efficient store of value.

"Efficient" is an attribute that should be viewed on two dimensions. The first is physical, and relates to low costs of storage and transport (the historical evolution of means of payments, from particular commodities, to precious metals, up to paper currencies can partly be explained by the search of this dimension of efficiency). The second is financial, and concerns the preservation of purchasing power over time. On this latter dimension, in a developed monetary economy, fiat (paper) money competes with other stores of value that have equally negligible storage and transport costs, but may outperform money in preserving purchasing power. Typically, these are interest-bearing financial assets. On the other hand, financial assets in general cannot be used as means of payment: they should be converted into money, or "liquidated", and this is usually a costly operation. Hence money retains a comparative advantage vis-à-vis financial assets in terms of liquidity. As a result, money and financial assets are substitutes, but not perfect substitutes, in households' portfolios.

These considerations lead to what Keynes called "the monetary nature of the interest rate", the relationship between the interest rate paid by financial assets and the propensity to use money as store of value, that is, the demand for money. It is worth emphasizing that, from this perspective, the demand for money relates to the side of the capital market 
(typically households) that owns money balances in excess of those allocated to current transactions in goods. The other side of the market (typically firms) wants money balances in addition to those currently available in order to employ them in additional purchases of goods (physical capital). Sales of financial assets are in fact a means to transfer money from the side of the market which is long in money to the side which is short in money. The crucial importance attributed to money demand (of the long side of the market) is that it affects the interest rate paid by firms and hence their investment plans. 8

\subsection{The demand for money and the LM equation}

The demand for money, as a relationship between the propensity to use money as store value and the interest rate on other assets, can be, and has been, articulated in a variety of approaches and models. A quite general distinction may be drawn between models where the interest rate is certain and those where it is uncertain.

Under certainty, the demand for money arises from the comparison between the opportunity cost of money (foregone interests) and the liquidity cost of assets (typically, fixed costs of conversion). The classical references here are the Baumol (1952) and Tobin (1956) "inventory models", or alternatively the "money in the utility function" approach inspired by Patinkin (1965) that has recently been applied extensively (see Walsh (2003, ch. 2)).

Under uncertainty, the actual return to an interest-bearing asset when the asset will be liquidated is not known with certainty ex ante. If $r_{t}$ is the fixed nominal interest rate paid by a corporate bond issued in period $t$, and $p_{b t}$ is its market price, then the actual return rate one period later will be

8 It may be interesting to note that the foregoing concept of money demand, established by Keynes, is somewhat counterintuitive (which may in fact explain the initial difficulties and misunderstandings that surrounded Keynes's monetary theory). From another point of view, in fact, one may say it is the short side of the capital market that exerts a proper demand for money whereas the long side of the market is in a position to grant the supply of money. On this view, the monetary counterpart of the private asset market gives rise to the market for "inside money", which redistributes the existing money stock within the private sector. This view was well developed in pre-Keynesian monetary and macroeconomic theories (e.g. Leijonhufvud (1981)). 


$$
\tilde{r}_{t+1}=\frac{r_{t}}{p_{b t}}+\hat{p}_{b t+1}
$$

where $\hat{p}_{b t+1}$ is the rate of change of the market price, which is the typical source of uncertainty over $\tilde{r}_{t+1}$. Therefore, in this context, the opportunity cost of money is given by the expected return to risky assets, while the liquidity cost of assets is given by prospective capital losses. This approach has led to the inclusion of money in portfolio analysis, as first put forward by Hicks (1935) and then fully developed by Tobin (1969).

In spite of the substantial differences across the various approaches, the specifications of the demand for money (as well as its empirical tests) boil down to a remarkably simple common core, which, in logs, reads as follows

$$
m^{d}{ }_{t}=p_{t}+m_{y} y_{t}-m_{r} r_{t}+u^{m}
$$

That is to say, the demand for money is exactly proportional to (or "homogeneous of degree 1" with) the GPL, positively related to the real value of transactions (e.g. output), and negatively related to the nominal interest rate on bonds. The variables in $u^{m}{ }_{t}$ and the parameters $m_{y}$ and $m_{r}$ reflect the different assumptions underlying the different models (e.g. Goodhart (1989)). For instance, in a simple inventory model under certainty $u^{m}{ }_{t}$ is proportional to the fixed liquidation costs and $m_{y}=m_{r}=0.5$. Under uncertainty, $u^{m}{ }_{t}$ is related to total financial wealth, and $m_{r}$ is weighted by the degree of risk aversion and the variance of the return to bonds, indicating that high risk and high risk aversion reduce the elasticity of money demand to the interest rate (or that risky assets are poorer substitutes for money). As a result, a higher interest rate is needed to induce a shift from money to bonds.

Equation (7) can be used to make explicit the relationship between interest rate and money. If $m_{t}$ is the stock of money available in the economy in period $t$, monetary equilibrium requires that $m_{t}=m_{t}{ }_{t}$. As a result, we obtain the Hicksian LM equation, which indicates the value of $r_{t}$ for which the money stock $m_{t}$ satisfies the demand $m^{d}$, i.e.

$$
r_{t}=\frac{m_{y}}{m_{r}} y_{t}-\frac{1}{m_{r}}\left(m_{t}-p_{t}\right)+\frac{1}{m_{r}} u_{t}^{m}
$$

As is clear from this equation, all the determinants of money demand, together with the real value of the stock of money in the economy $\left(m_{t}-p_{t}\right)$, influence the interest rate and all interest-sensitive expenditures. 


\subsection{The LM and inflation}

It is convenient to recast at once the demand for money and the LM equation in our macroeconomic framework. In the first place, we may wish to see how much money the economy demands on the trend. Given the potential output $y^{*}$ and the NAIRI $r^{*}$, equation (7) gives us the answer for a constant GPL. If on the trend the GPL grows at the constant rate $\pi^{*}$, we should first understand how inflation affects money demand. This is quite simple to see. Starting on trend in any period, the time first difference of equation (7) indicates by how much money demand may change in the next period, i.e.

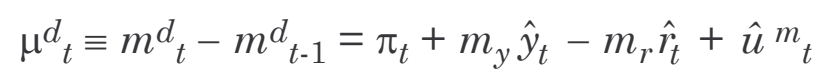

Hence, on the trend $\left(\hat{y}_{t}, \hat{r}_{t}, \hat{u}_{t}^{m}\right)=0$, money demand grows one-to-one with the inflation rate as a direct consequence of the increasing value of transactions. Consequently, monetary equilibrium requires an equivalent growth rate of the money stock, $\mu^{*}=\pi^{*}$.

This condition is important: among other reasons, because it guarantees that the interest rate coincides with the NAIRI. In fact, we can use the LM equation (8) to examine the consequences on $r_{t}$ of the economy being off the trend. Actually, what we need is a LM "gap equation" that indicates how $r_{t}$ may deviate from $r^{*}$, i.e.

$$
\hat{r}_{t}=\frac{m_{y}}{m_{r}} \hat{y}_{t}-\frac{1}{m_{r}}\left(\hat{\mu}_{t}-\hat{\pi}_{t}\right)+\frac{1}{m_{r}} \hat{u}_{t}^{m}
$$

Therefore, apart from exogenous money demand shocks $\hat{u}_{t}{ }_{t}$, the interest rate may deviate from the NAIRI in response to output gaps, inflation gaps or too fast/slow money growth.

First of all, the reader can check that, as argued above, as long as output and inflation are on the trend $\left(\hat{y}_{t}=0, \hat{\pi}_{t}=0\right)$, and $\hat{u}_{t} m_{t}=0, \hat{\mu}_{t}=0$ indeed guarantees that $r_{t}=r^{*}$. Otherwise, excessive or insufficient $\mu_{t}$ with respect to $\mu^{*}$ makes $r_{t}$ increase or decrease with respect to $r^{*}$. On the other hand, if $\hat{\mu}_{t}=0, r_{t}$ may still increase or decrease according to the rise or fall in the demand for transaction balances (in real $\left(\hat{y}_{t}\right)$ and/or nominal $\left(\hat{\pi}_{t}\right)$ terms), or to exogenous shocks $\hat{u}^{m}{ }_{t}$. The positive relation between interest rate gaps and inflation gaps is interesting and corresponds to the so-called "real balance effect" in an inflationary context. To see this point more clearly suppose that all variables are at their trend values $\left(\hat{y}_{t}=0, \hat{u}_{t} m_{t}=0, \hat{\mu}_{t}=0\right)$ except excess inflation $\left(\hat{\pi}_{t}>0\right)$. In this situation the trend money growth rate $\mu^{*}$ is no longer commensurate to actual inflation, the real value of 
money balances falls, the economy develops excess money demand and the interest rate increases.

\section{Alternative monetary regimes: exogenous vs. endogenous money}

We have now all the elements for a complete system of AD, AS, LM equations "in gaps" that describes how the economy may deviate from the trend. Imposing that the output market clears in each period, $\hat{y}_{t} d=\hat{y}_{t}^{s}$, we obtain

$$
\begin{aligned}
& \hat{y}_{t}=-y_{r} \hat{r}_{t}+\hat{u}_{t} \\
& \hat{\pi}_{t}=\frac{1}{y_{w}} \hat{y}_{t}-\hat{u}_{t}^{s} \\
& \text { a) } \hat{r}_{t}=\frac{m_{y}}{m_{r}} \hat{y}_{t}-\frac{1}{m_{r}}\left(\hat{\mu}_{t}-\hat{\pi}_{t}\right)+\frac{1}{m_{r}} \hat{u}_{t}^{m} \\
& \text { b) } \hat{\mu}_{t}=\hat{\pi}_{t}+m_{y} \hat{y}_{t}-m_{r} \hat{r}_{t}+\hat{u}_{t}^{m_{t}}
\end{aligned}
$$

The system consists of three equations, the last two being alternative specifications of the LM. These reflect the alternative choice between two monetary policy instruments to which there correspond two different monetary regimes. In the case a), the economy is said to be in a regime of exogenous money: the central bank controls $\mu_{t}$ and lets $r_{t}$ be determined by the market. In the case b), the economy is in a regime of endogenous money: the instrument is $r_{t}$ and the determination of $\mu_{t}$ is left to the market. The two regimes will be discussed below.

Given the set of trend variables $\left(y^{*}, \pi^{*}, r^{*}, \mu^{*}\right)$ and any of the shocks $\left(\hat{u}_{t}{ }_{t}, \hat{u}_{t}^{s}, \hat{u}_{t}^{m}\right)$, the system allows for determination of three endogenous "gap" variables $\left(\hat{y}_{t}, \hat{\pi}_{t}, \hat{r}_{t}\right.$ or $\left.\hat{\mu}_{t}\right)$, This ensures that the system is determinate. Moreover, for $\left(\hat{u}_{t}{ }_{t}, \hat{u}_{t}^{s}, \hat{u}^{m}\right)=0$, it admits of a configuration consistent with the economy being on the trend, namely $\left(\hat{y}_{t}, \hat{\pi}_{t}, \hat{r}_{t}, \hat{\mu}_{t}\right)=0$. It also highlights two main classes of phenomena that may shift the economy off the trend:

- real shocks, either from the $\mathrm{AD}$ side $\left(\hat{u}_{t}^{d}\right)$ or from the AS side $\left(\hat{u}_{t}^{s}\right)$

- monetary shocks, either from the demand side $\left(\hat{u}_{t}^{m_{t}}\right)$ or from the supply side $\hat{\mu}_{t}, \hat{r}_{t}$ 
The point on which we focus in this section is the role of monetary policy within this picture. The main messages of today's "majority view" are two. First, do not disturb the economy with undue money supply shocks. For the economy to remain on the trend, the money stock should grow at the trend inflation rate, otherwise the interest rate deviates from the NAIRI and feeds off-trend movements of $\mathrm{AD}$ and AS. Second, in the presence of other exogenous shocks, monetary policy should implement a suitable stabilization policy driving the economy back on trend.

Both recommendations require accurate understanding of how monetary policy works and can be implemented, which is beyond our scope here. Suffice it to consider the preliminary and fundamental issue concerning the choice of the policy instrument between the money growth rate or instead the interest rate.

\subsection{Exogenous money}

This term indicates that the central bank has direct control of (and adopts as instrument) the process of money growth $\mu_{t}$; consequently, the interest rate is the dependent variable of the LM equation, that is, it is determined endogenously by the monetary equilibrium conditions, the other variables in the equation being given. Typically, the central banks that opt for this regime (e.g. the former Bundesbank in Germany, and now, in part, the European Central Bank in the euro area) announce a target for the money growth rate and operate accordingly. Our model, as explained above, also indicates what this target should be as long as the economy is on the trend. The proportionality between the growth rate of the money stock and the inflation rate along the general equilibrium path of the economy was (re)established in the post-Keynes era by Friedman (1968) and his Monetarist school. He spelt it out in his well-known slogan of the "k\% growth rule", which can therefore be called the "Friedman rule". This view had a strong influence on the theory and practice of monetary policy for the subsequent two or three decades.

It may be added that the Monetarists were also convinced that there was no particular need for the central bank to intervene actively to stabilize the economy even in the presence of exogenous shocks. Their idea was that the real part of the system (equations (11) and (12)) is inherently resilient to shocks, even though the money growth rate is just kept in line with its trend value. A preliminary check of this claim can be done upon noting that, in the 
exogenous money regime, the LM equation (13)(a) can be substituted for $\hat{r}_{t}$ into the $\mathrm{AD}$ equation (11). As a result, as long as $\hat{\mu}_{t}=0, \mathrm{AD}$ is decreasing with respect to $\hat{\pi}_{t}$ (e.g. $\hat{\pi}_{t}<0$ ceteris paribus lowers the interest rate which stimulates $\mathrm{AD}$, see Figure 1). This is equivalent to the textbook $\mathrm{AD}$ equation decreasing with the GPL. Since the AS function is increasing with $\hat{\pi}_{t}$, elementary market stability analysis suggests that the system is stable.

Figure 1. The AD and AS "gap functions"

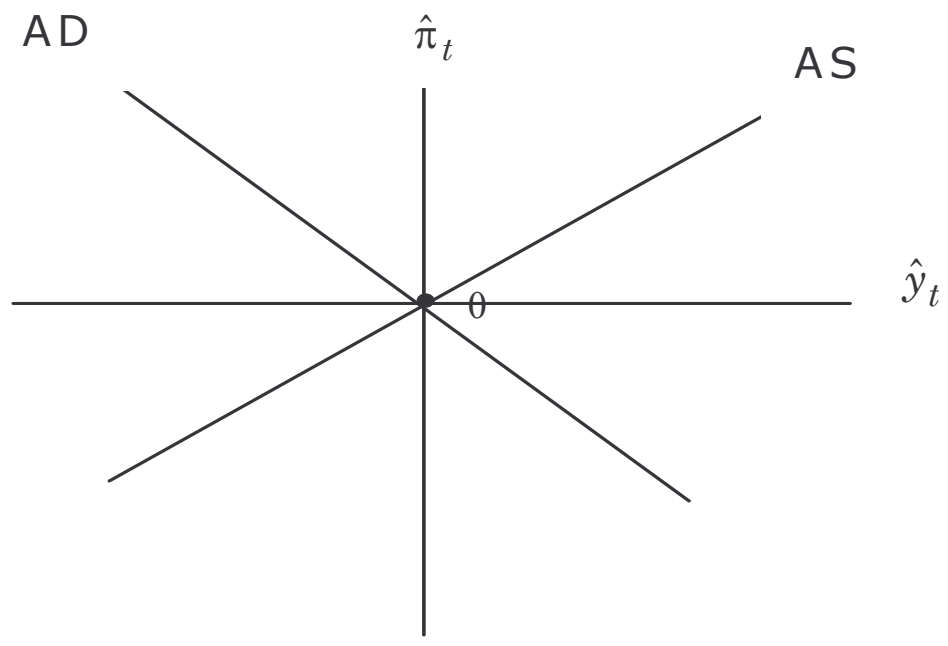

In order to gain a better assessment of the Monetarist approach it may be useful to see the model at work by means of simulations. To this end, our system should be enriched with a proper dynamic structure of "leads and lags". The simplest, yet sufficient, modification consists of adding a lagged output gap term to the r.h.s. of the $\mathrm{AD}$ equation (11). As a matter of fact, there is ample evidence that output gaps display some autocorrelation or "inertia" (e.g. Sims (1992)). The trend inflation rate is fixed at $\pi^{*}=2 \%$, so that $\mu^{*}=2 \% .9$

9 The other parameters of the model have been set with reference to broad empirical regularities of developed countries, namely, an autocorrelation coefficient of 0.3 , an $\mathrm{AD}$ elasticity to interest rate gaps $y_{r}=0.2$, an AS elasticity to inflation gaps $y_{w}=2.0$ (remember that $y_{w}=\alpha /(1-\alpha)$; this is, according to the underlying Cobb-Douglas production function, the labour to capital income ratio which is roughly of that order of magnitude), and finally the income and interest elasticities of money demand $m_{y}=m_{r}=0.5$ (these values are taken from the Baumol-Tobin inventory model; actually, there has never been sufficient agreement on estimated money demand functions, except that the two parameters do not exceed unity and the interest elasticity is no greater than the income elasticity - e.g. Goodhart (1989)). 
Now let us look at Figure 2, the simulation of a 1\% exogenous fall in $\mathrm{AD}$ with the money growth rate left unchanged. After the initial AD shock that reduces output and inflation, the interest rate falls spontaneously and progressively drives the system back to trend. Essentially, the real balance effect is at work here: monetary policy remains passive, but as long as inflation is below its trend value, the trend money growth corresponds to an expansionary impulse that increases real money balances with the effect of reducing the interest rate below the NAIRI. It is worth stressing that the model, as well as the simulation, are based on the assumption that all agents' inflation expectations are anchored to the belief that the inflation rate will eventually return to its trend value. This belief is in fact supported by the system, so that it can also be qualified as "rational expectation".

Figure 2. Simulation of $1 \%$ exogenous fall in aggregate demand

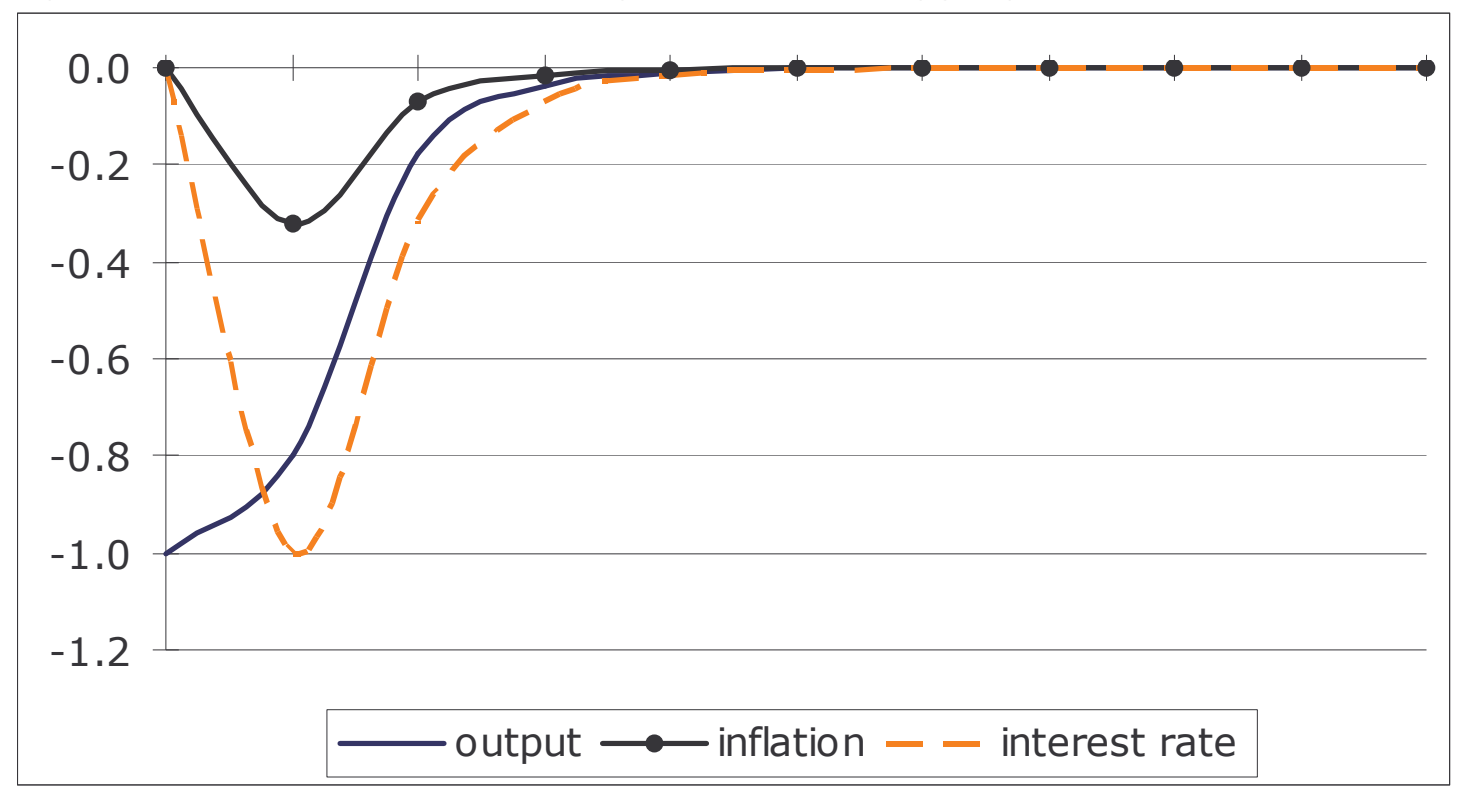

Probably, the best known argument of Monetarism is that "activist monetary policy", that is to say on-off deviations from the Friedman rule, have only temporary effects on output (and employment) at the cost of creating cyclical swings in the economy.

Figure 3 illustrates this point by simulating an on-off $1 \%$ spike in the money growth rate. After the initial fall in the interest rate and increase of output, 
inflation starts accelerating. With money growth back to the trend value, monetary policy has a restrictive effect. The underlying mechanism is again the real balance effect, with reversed sign.

Figure 3. Simulation of $1 \%$ temporary increase in the money growth rate

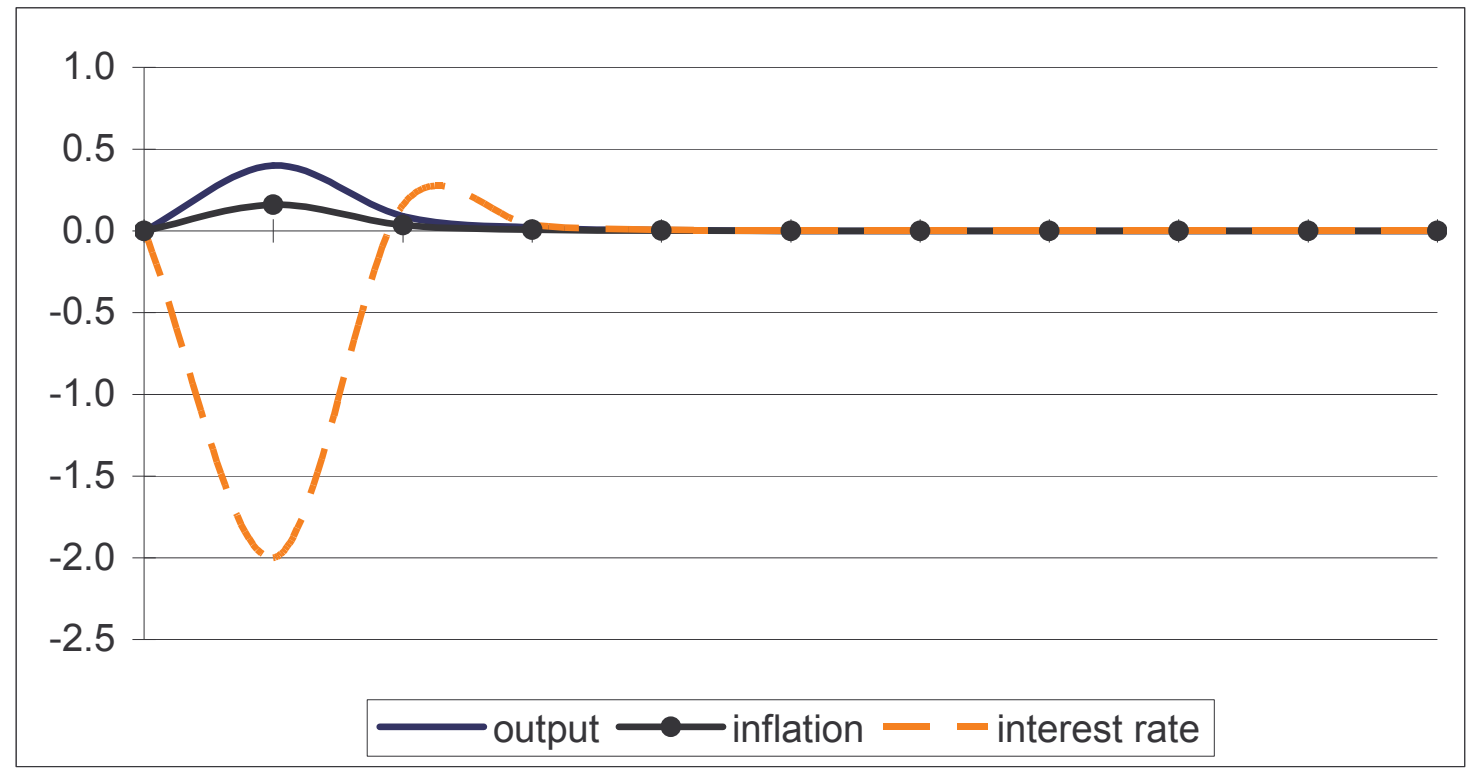

The idea that monetary policy should be anchored to a fixed rule, rather than being left to the "discretion" of the central banker under contingent circumstances is a permanent legacy of Monetarism. The milestone papers by Kydland and Prescott (1977), Barro and Gordon (1983), showed that even a benevolent central banker promising "to do the best for the economy in any contingent situation" (e.g. push output above trend if there is unemployment) may end up with an inflation rate higher than the historical trend with no permanent increase in output and employment. Suppose that a central banker, having learned that on-off monetary impulses have only transitory effects, sets out to raise output by means of a permanent increase in the money growth ("inflationary bias"). With the help of the rational expectations hypothesis (which was still undeveloped at the early stages of Monetarism) it was possible to show that this would be an inconsistent policy with respect to monetary equilibrium. In fact, if the new 
money growth rate is $\mu^{\prime}$, then monetary equilibrium, that is $\hat{r}_{t}=0$ for all future $t$, implies a new inflation rate $\pi^{\prime}=\mu^{\prime}$. Anticipating this result, rational agents will immediately revise their expected inflation rate in nominal contracts nullifying any real effect of the policy change. The reader can easily check that, upon substituting $\mu^{\prime}$ into the LM equation (13)(a) this yields $\hat{r}_{t}=0$ for $y_{t}=y^{*}$ (the previous potential output) and $\pi_{t}=\pi^{\prime}$ (the new, higher, inflation rate).

This result is important also in relation to the question of the indeterminacy of the trend inflation rate because of Say's Law, since it suggests that what the trend inflation rate is depends on the central bank's ability to set a credible inflation target for the economy. 'Credible' means that if the announced target is $\pi^{*}$, agents have reasons to believe in this target: they adopt it in their forecasts as shown in the various steps of the model, and their expectations are in fact fulfilled. On paper, therefore, the trend inflation rate is an entirely conventional variable in the hands of the central bank, meaning, by the way, that there is no apparent reason why it should be greater than zero. In practice, however, there are various reasons why the historical inflation rates in almost all countries, and the target inflation rates of all major central banks, cannot be, and are not, zero. Thus, if the trend inflation rate contains some structural components (the longrun growth rate of commodity world prices, say) then a central bank willing to keep too a low inflation rate would make a mistake ("deflationary bias") that would jeopardize the system's stability.

\subsection{Endogenous money}

By this term is meant that the central bank has direct control of (and adopts as an instrument) the nominal interest rate $r_{t}$, so that the money growth rate is the dependent variable of the LM. More precisely, once $r_{t}$ is set, the central bank must be ready to inject into the system any amount of money that is consistent with money demand according to equation (13)(b). If the exogenous money regime is closely related with Monetarism and the "Friedman rule", the endogenous money regime is the hallmark of NewKeynesianism and the "Taylor rule" (Taylor (1993)) ${ }^{10}$. This is a rule in a

10 Endogenous money comes from a long-standing tradition in monetary theory that was well entrenched in the Old Keynesianism as well (see Tobin (1970), Kaldor (1982), Moore (1988)). On the opposite front, too, the New Classical theorists of real business cycles, denying any real effect of monetary variables. are 
different sense than Friedman's in that it does not fix a determinate value of the control variable irrevocably but indicates how the central bank changes the control variable in relation to changes in specified conditions in the economy. Hence a better term is that of a "reaction function" which makes monetary policy transparent and predictable, though not predetermined (Blinder (1998)).

The basic specification of the Taylor rule can easily be translated into our framework as follows

$$
\hat{r}_{t}=\gamma \hat{y}_{t}+\delta \hat{\pi}_{t}
$$

That is to say, the central bank commits itself to setting the nominal interest above or below the NAIRI if output and/or inflation are above or below their respective trend values. The parameters $\gamma$ and $\delta$ are related to the central bank's policy weights assigned to output vis-à-vis inflation stabilization. These weights may also be obtained by assuming (or imposing) that the central bank minimizes a loss function defined over output and inflation gaps (Clarida et al. (1999)).

Much of the scholarly work subsequent to Taylor's "discovery" of how the US Federal Reserve engineers its control of the interest rate has mainly focused on three issues: whether the empirical evidence extends over time and in other countries, whether reaction functions such as the Taylor rule do have stability properties (such as those of the Friedman's rule seen above), whether the Taylor rule can be designed so as to maximize welfare in the face of macroeconomic shocks (Clarida et al. (1999), Woodford (2003)). Here we shall consider the second issue in the context of our macro-model.

This issue is typically addressed by combining a Taylor rule with an output gap and an inflation gap equation: in our case, equations (11), (12) and (14). We can now repeat the same preliminary stability check as in the case of the exogenous money regime: let us use equation (14) to substitute for $\hat{r}_{t}$ in equation (11) to obtain the relationship between $\hat{y}_{t}$ and $\hat{\pi}_{t}$. It is immediately seen that, as long as $\delta>0, \hat{y}_{t}$ remains decreasing with respect to $\hat{\pi}_{t}$ as it was in the exogenous money regime. The important conclusion is that the endogenous money regime is consistent with stability as much as

ready to subscribe to the view that the co-movements between output and money aggregates are the result of the latter being driven by the former rather than the other way round (see e.g. King and Plosser (1984)) 
the exogenous money regime provided that the interest-rate reaction function is responsive to inflation gaps (note that from this point of view the responsiveness to output gaps is not necessary). ${ }^{11}$

To see this point more clearly, we can simulate the new system and examine how it reacts to the same $\mathrm{AD}$ negative shock that we imparted to the exogenous money system above. The structural parameters of the AD and AS functions are the same. The policy weights of the Taylor rule have been set equal to those found in Taylor's original paper, namely $\gamma=0.5$ and $\delta$ $=1.5$. As can be seen from Figure 4, the qualitative dynamic pattern of the economy is in fact analogous to the exogenous money regime.

Figure 4. Simulation of $1 \%$ exogenous fall in aggregate demand

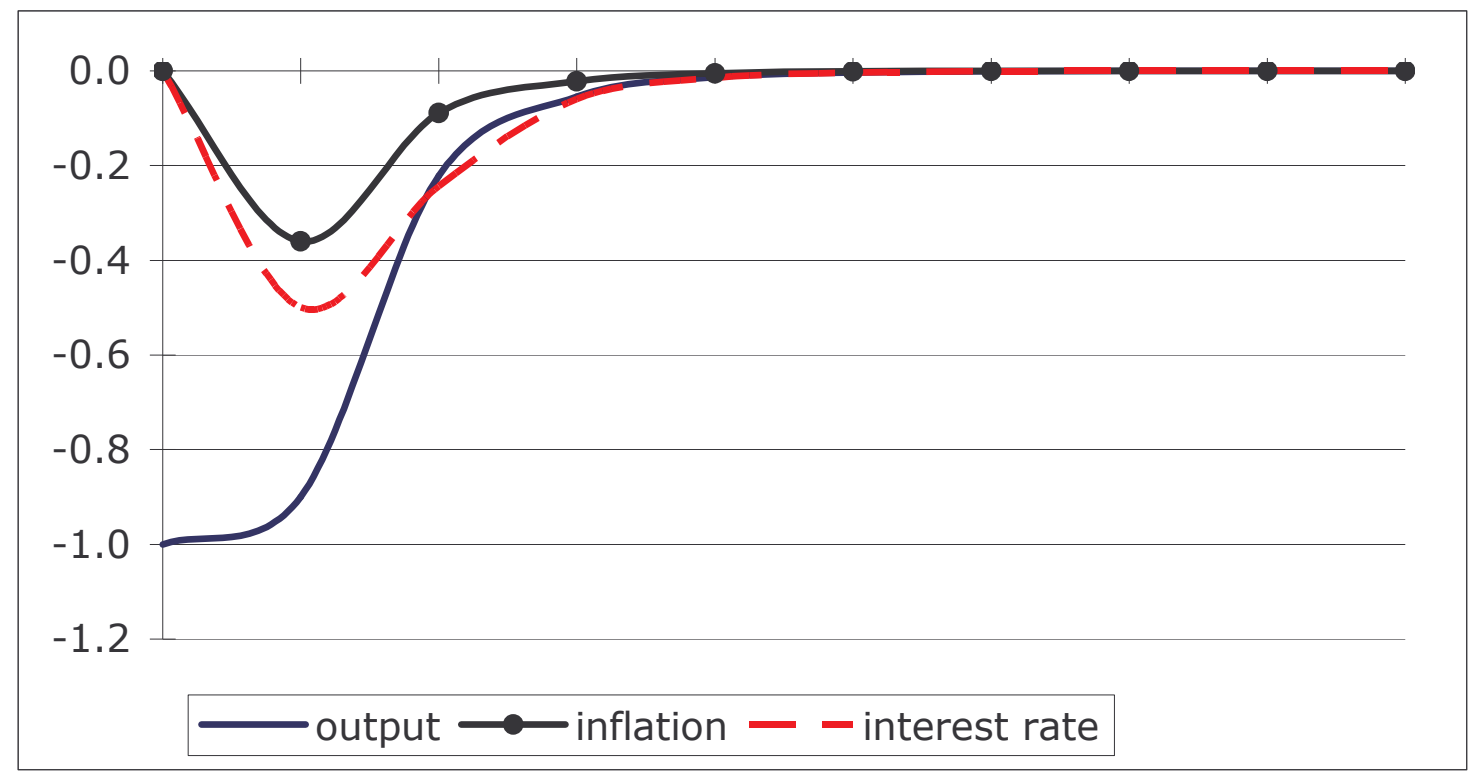

It is also worth drawing attention to the fact that, contrary to the Friedman rule, the Taylor rule implies an active monetary policy. In fact, the Taylor rule commits the central bank to intervening in the face of macroeconomic shocks whereas, as seen above, the Friedman rule does not. Indeed, in the endogenous money system the nominal interest rate provides the single link between the monetary and the real side of the economy, and if the central bank does not intervene on $\hat{r}_{t}$, the system will not adjust spontaneously to shocks. This, it should be stressed, is an extreme characterization of the endogenous money system due to the structure of the

11 If the reaction function has zero weight on output gaps, then we are in a pure "inflation targeting" regime (see e.g. Svensson (1997)). 
AD-AS-TR system, where the interest rate, in the absence of active monetary policy, would be totally unrelated to changes in inflation or output. This is not the case with the LM function thanks to the real balance effect. As a matter of fact, it is a long-standing argument of Old and New Keynesians (e.g. Greenwald and Stiglitz (1987), (1993)) that the real balance effect is empirically weak and negligible. This fact may provide an additional argument in favour of the direct control of the interest rate by the central bank. Yet it does not seem recommendable that the non-policy linkages between the interest rate and the other macro-variables are completely hidden from view.

At this point, an important methodological issue should be stressed. The bare AD-AS-TR framework may transmit the faulty idea that the central bank can set the interest rate at will with no connection at all with money demand and supply. This is certainly not the case, and a correct and complete representation of the endogenous money regime should include the endogenous LM equation (13)(b). Hence we end up with the four equations system that I reproduce here for the reader's convenience:

$$
\begin{aligned}
& \hat{y}_{t}=-y_{r} \hat{r}_{t}+\hat{u}_{t}{ }_{t} \\
& \hat{\pi}_{t}=\frac{1}{y_{w}} \hat{y}_{t}-\hat{u}_{t}{ }_{t} \\
& \hat{r}_{t}=\gamma \hat{y}_{t}+\delta \hat{\pi}_{t} \\
& \hat{\mu}_{t}=\hat{\pi}_{t}+m_{y} \hat{y}_{t}-m_{r} \hat{r}_{t}+\hat{u}^{m}{ }_{t}
\end{aligned}
$$

This format of the system highlights that controlling the interest rate by means of the Taylor rule implies an endogenous evolution of the money stock determined by the inflation gap, the output gap and the Taylor rule itself. Thus, the explicit consideration of the endogenous money growth process may convey interesting bits of knowledge and information. Two examples are the following.

First, let us consider again the case of a negative AD shock. As can be understood form the equation of $\hat{\mu}_{t}$, this variable results from two opposite tendencies: the $\mathrm{AD}$ negative shock tends to reduce money demand both in nominal and real terms, the subsequent cut of the interest rate tends to raise it. The overall outcome cannot be predicted a priori as it depends on the magnitude of the relevant parameters. Figure 5 shows the path of the money growth rate underlying the Taylor-rule-driven adjustment process to 
the negative $1 \% \mathrm{AD}$ shock in Figure 4 . The deflationary shock causes a net deceleration of the money growth rate even though the central bank lowers the interest rate. This seemingly odd result is due to the fact that the simulated Taylor rule yields a relative small cut in the interest rate (compare Figure 4 and 2) which is not sufficient to overcome the negative effect of the deflationary shock on money demand (indeed, the Taylor rule is engineered to close the output and inflation gaps, not to control the money growth rate). Therefore, it is interesting to note that the sign of the change in the money growth rate may not give the right information on the actual monetary policy stance.

Figure 5. Path of the money growth rate after a $1 \%$ fall in aggregate demand under the Taylor rule

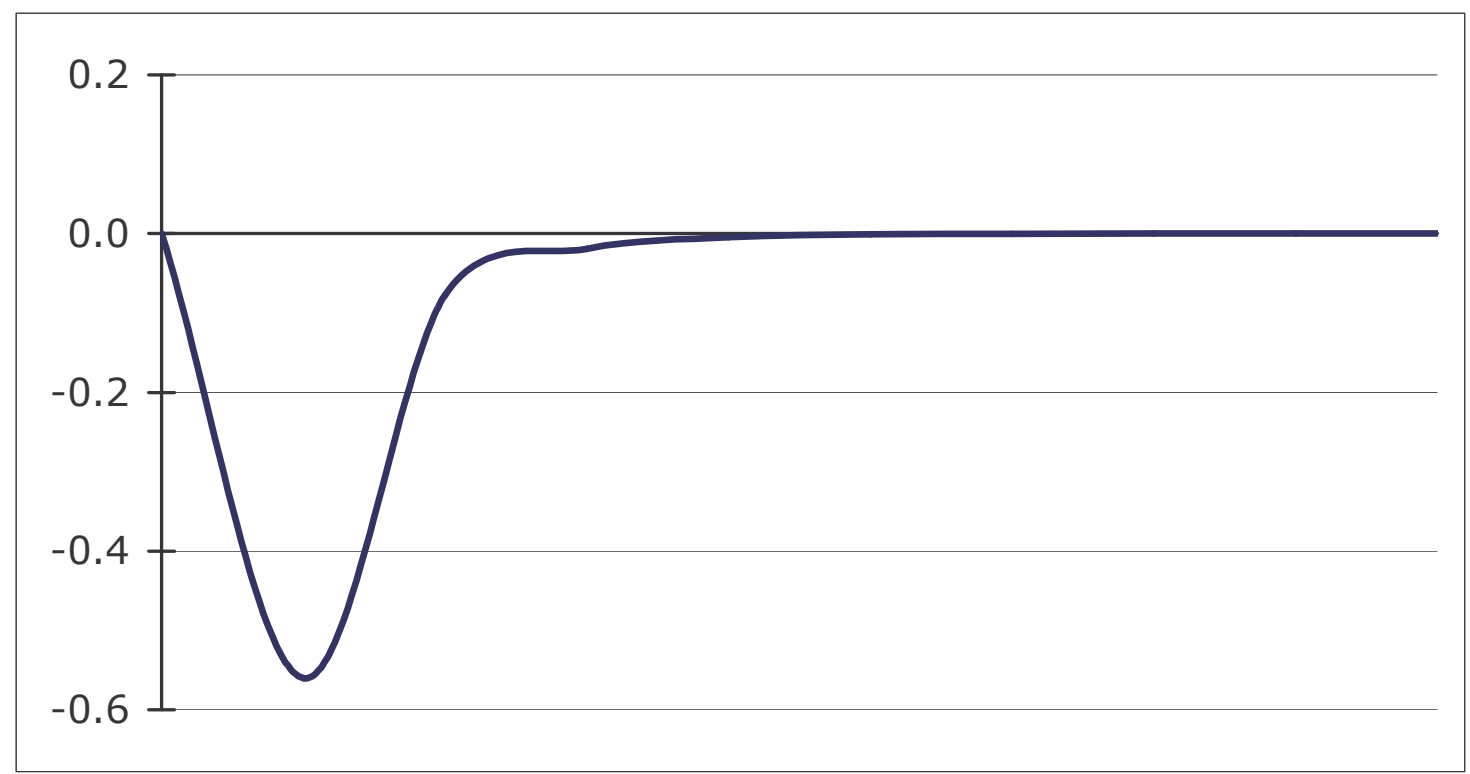

As a second example, note that equation (13)(b) contains the money demand disturbance $\hat{u}_{t}^{m}$, which is notably absent from the Taylor rule. On the other hand, one major argument in favour of direct interest-rate control is that these disturbances are wide and frequent. What happens to them in the endogenous money regime? If they are not explicitly included in the Taylor rule, they have to be accommodated by way of the money market operations (see Walsh (2003, ch. 9)). If , say, $\hat{u}_{t}^{m_{t}}>0$ and $\hat{r}_{t}=0$, the supply side of the money market (through its different articulations) must be ready to inject more money at the current interest rate. This explains why these disturbances are the main source of difficulty for the central bank (and for 
the central bank watchers) in using the money growth rate as a precise signal of monetary policy.

It has been stressed above that in the basic endogenous money system changes in the money growth rate are ignored on the presumption that they have no impact on the real part of the economy, which only responds to the interest rate, and have no impact on the interest rate, which is only determined by the central bank. To the extent that these presumptions cannot be taken at face value, as argued by the Monetarists, tracking the evolution of the money growth rate may still find a place in the monetary policy conduct (see e.g. B. Friedman (2003)) ${ }^{12}$.

\subsection{Which monetary regime?}

A major advantage of the monetary framework presented here is that it allows for an integrated, comparative analysis of the two regimes (neither of which is posited as an article of faith). On the one hand, this analysis helps establish the principle that the two regimes are alternative, in the sense that they cannot be adopted simultaneously ${ }^{13}$. It is also clear that, on the other hand, both alternatives are rooted in the concept of monetary equilibrium that has been explained in the previous paragraphs.

First of all, comparison between the LM equation (13)(a) with the Friedman rule, and equation (14) with the Taylor rule reveals that the two regimes yield an interest-rate equation which is formally identical (apart from money demand shocks, see below). No surprise, then, that the two regimes have the analogous stability properties that we found above. Therefore, we may conclude that there is no fundamental theoretical difference between the two regimes, and the choice between them is essentially on operational grounds in consideration of the structural features of the economy and the way in which these impinge upon the conduct of monetary policy.

12 This conclusion might mitigate the fierce criticism towards the ECB "twohanded" monetary policy of interest-rate control with money-growth monitoring.

13 As a relevant example, the European Central Bank is being criticized since its inception because it declares that its policy is based on "the two pillars" of the control of the money growth rate and the control of interest rates (e.g. ECB (1999)). Since these two pillars cannot stand together, critics argue that monetary policy by the ECB is in fact opaque and unaccountable. See e.g. Wyplosz (2006). 
The classic reference in this perspective is still Poole's (1970) analysis which showed that the exogenous money regime is preferable (in terms of stability) to the extent that the demand for goods is more volatile than the demand for money (e.g. the variance of $\hat{u}^{m}{ }_{t}$ is smaller than the variance of $\hat{u}_{t}{ }_{t}$ ), whereas the endogenous money regime is preferable in the opposite case. As a matter of fact, the dramatic increase in money demand volatility with respect to $\mathrm{AD}$ volatility that has occurred in all major industrialized countries over the last decades, mostly as a consequence of financial innovations, has been the main force driving major central banks away from money quantitative control and towards the (overt) direct control of the interest rate (Moore (1988), Goodhart (1988)).

Of paramount importance in this connection is the role of the banking sector. Our framework (like all standard textbook treatments) is kept at a level that does not accommodate this sector explicitly, and this represents a critical simplification for both monetary regimes. As a matter of fact, in developed systems the central bank has no direct relations with the nonbank private sector. Also, the real-world monetary variables most relevant to the non-bank private sector - bank deposits and their close substitutes as to money demand, and corporate bond rates as to the interest rate - are not directly controllable by the central bank. The "transmission mechanism" between these variables and their counterparts within the reach of the central bank - bank reserves and inter-bank interest rates, respectively goes through the banking sector. And therefore, the matching process between money demand and money supply, whether it takes place in one regime or the other, is intermediated by the banking sector. The old Monetarist presumption that this fact could be safely ignored (as in Friedman's well-known metaphor of money being dropped onto the public from an helicopter) or that it could be tamed by the mechanics of the "money multiplier", has in the long run proved to be untenable. Contrary to that presumption, and as a vindication of Keynesian criticisms, developments in the banking sector and its increasing sophistication have dramatically weakened and blurred the transmission mechanism between "high powered money" and the final money stock in the hands of the public that underpinned the Monetarist theory and practice of the exogenous money regime. On the other hand, the New Keynesian theory and practice of the endogenous money regime is no less crucially dependent upon very delicate, and perhaps transient, transmission mechanisms; the demand and supply of 
bank reserves in the first place, and the term structure of interest rates in the second place (Romer (2000), Walsh (2003, ch. 9)). Therefore, the ideal extension of the basic model of either monetary regime at a more advanced level should include the inter-bank market as the true money market where monetary policy is conducted.

\section{Conclusions}

Ongoing developments in macroeconomics and in the theory and practice of monetary policy render increasingly flimsy, obsolete and awkward the teaching of the traditional LM apparatus as a means to determine the interest rate and to provide the link between the monetary and the real side of the economy. On the other hand, although replacement of the LM with the Taylor rule may make those tasks more immediately intelligible and tangible, it conveys the wrong ideas that the central bank has no other means to conduct monetary policy, that it can set the interest rate at will with no connection with the money market equilibrium, and that there is no other non-policy relationship between the interest rate and output and inflation. This paper has put forward a macroeconomic framework of New Keynesian inspiration which shows how overcome the drawbacks of both the old LM and the new TR by amending the LM block rather than suppressing it.

The model consists of AD, AS and LM functions that are consistently re-expressed in terms of output gaps and inflation gaps, and shows that once the LM apparatus has been properly re-worked in this way, it has no faults and fits the general framework perfectly. Indeed, it may be used to explain that the central bank can choose between controlling the money growth rate or the nominal interest rate, and that the latter choice may be represented by the Taylor rule. By showing that the two policy regimes are formally equivalent and have analogous stability properties, the model clarifies that the central bank's choice is mainly dictated by considerations of operational efficiency, as is very well-known from the literature on central banking. It also makes clear that controlling the interest rate implies a path of the money growth rate dictated by the underlying money market 
equilibrium. This saves an important conceptual point, and allows consistent extensions of the model to include the role of the inter-bank market as the actual place where monetary policy is conducted.

\section{References}

Allsopp C., Vines D. (2000), "The Assessment: Macroeconomic Policy", Oxford Review of Economic Policy, 16, pp. 1-32.

Barro R. J., Gordon D. B. (1983), "A Positive Theory of Monetary Policy in a Natural-Rate Model", Journal of Political Economy, 91, pp. 589-610.

Baumol W. (1952), "The Transactions Demand for Cash", Quarterly Journal of Economics, 67, pp. 545-556.

Blanchard O. J. (2000), "What Do We Know about Macroeconomics that Fisher and Wicksell Did Not Know?", Quarterly Journal of Economics, 115, pp.1375-1409.

Blanchard O. J., Kiyotaki N. (1987), "Monopolistic Competition and the Effects of Aggregate Demand", American Economic Review, 77, pp. 647-666.

Blinder A. (1998), Central Banking in Theory and Practice, Cambridge (Mass.): MIT Press.

Carlin W., Soskice D. (2004), "The 3-Equation New Keynesian Model: A Graphical Exposition", Discussion Paper Series, CEPR, n. 4588.

Clarida R., Galì J., Gertler M. (1999), "The Science of Monetary Policy: A New Keynesian Perspective", Journal of Economic Literature, 37, pp.1661-1707.

European Central Bank (1999), Monthly Bullettin, n. 1.

Friedman B. M. (2003), "The LM Curve: A Not-so-fond Farewell", NBER Working Paper Series, n. 10123.

Friedman M. (1957), A Theory of the Consumption Function, Princeton (N.J.): Princeton University Press.

Friedman M. (1968), "The Role of Monetary Policy", American Economic Review, 58, pp. 1-17.

Goodfriend M., King R. G. (1997), "The New Neoclassical Synthesis and the Role of Monetary Policy", in Bernanke B.S., Rotemberg J.J. (eds.), NBER Macroeconomics Annual, Cambridge (Mass.): MIT Press.

Goodhart C. A. (1988), "The Conduct of Monetary Policy", Economic Journal, 98, pp. 330-365.

Goodhart C. A. (1989), Money, Information and Uncertainty, London: Macmillan, 2nd. ed.

Greenwald B, Stiglitz J. E. (1987), "Keynesian, New Keynesian and New Classical Economics", Oxford Economic Papers, 31, pp. 119-133.

Greenwald, B.C., Stiglitz, J.E. (1993), "New and Old Keynesians", Journal of Economic Perspectives, 7, pp.23-44.

Hahn F. H. (1982), Money and Inflation, Oxford: Blackwell. 
Heymann D., Leijonhufvud A. (1995), High Inflation, Oxford: Clarendon Press.

Hicks J. R. (1935), "A Suggestion for Simplifying Monetary Theory", in Critical Essays in Monetary Theory, Oxford: Clarendon Press, 1965.

Kaldor N. (1982), The Scourge of Monetarism, Oxford: Oxford University Press.

Keynes J. M. (1937a), "Alternative Theories of the Rate of Interest", Economic Journal, 47, pp. 201-215

Keynes J. M. (1937b), "The General Theory of Employment", Quarterly Journal of Economics, 14, pp. 109-123.

King R.G., Plosser C.I. (1984), "Money, Credit and Prices in a Real Business Cycle", American Economic Review, 74, pp.363-380.

Kydland F. E., Prescott E. C. (1977), "Rules Rathar Than Discretion: The Inconsistency of Optimal Plans", Journal of Political Economy, 85, pp. 473-491.

Leijonhufvud A. (1981), "The Wicksell Connection. Variations on a Theme", in Information and Coordination: Essays in Macroeconomic Theory, New York: Oxford University Press.

Leijonhufvud A. (1983) "What Was the Matter With IS-LM?", in J. P. Fitoussi (ed.), Modern Macroeconomic Theory, Oxford: Blackwell.

Lucas R. E. (1977), "Understanding Business Cycles", Journal of Monetary Economics, in Brunner K, Meltzer L. H. (eds.), Stabilization of the Domestic and International Economy, Amsterdam: North Holland.

Mankiw G. N. (1989), "Real Business Cycles: A New Keynesian Perspective", Journal of Economic Perspectives, 3, pp.79-90.

Mankiw N. G., Romer D. (1991), New Keynesian Economics, 2 vols., Cambridge (Mass.): MIT Press.

McCallum B. T., Nelson E. (1999), "An Optimizing IS-LM Specification for Monetary Policy and Business Cycle Analysis", Journal of Money, Credit and Banking, 31, pp. 296-316.

Modigliani F., Brunberg R. (1954), "Utility Analysis and the Consumption Function. An Interpretation of Cross-Section Data", in Kurihara K.K. (ed.), Post Keynesian Economics, New Brunswick N.J.: Rutgers University Press.

Moore B. (1988), Horizontalists and Verticalists, Cambridge: Cambridge University Press.

Patinkin D. (1965), Money, Interest and Prices: An Integration of Money and Value Theory, New York: Harper \& Row, 2nd. ed.

Phelps E. S. (1968), "Money Wage Dynamics and Labour Market Equilibrium", Journal of Political Economy, 76, pp. 678-711.

Phelps E .S. (ed.) (1970), Microeconomic Foundations of Employment and Inflation Theories, New York: Norton.

Poole W. (1970), "Optimal Choice of Monetary Policy Instruments in a Simple Stochastic Macro Model", Quarterly Journal of Economics, 84, pp. 197-216. 
Romer D. (2000), "Keynesian Macroeconomics Without the LM Curve", Journal of Economic Perspectives, 14, pp. 149-169.

Sims C. (1992), "Interpreting the Macroeconomic Time Series Facts: The Effects of Monetary Policy", European Economic Review, 36, pp. 9751000.

Svensson L. E. O. (1997), "Inflation Forecast Targeting. Implementing and Monitoring Inflation Targets", European Economic Review, 41, pp. 1111-1147.

Taylor J. B. (1980), "Aggregate Dynamics and Staggered Contracts", Journal of Political Economy, 88, pp. 1-24.

Taylor J. B. (1993), "Discretion Versus Policy Rules in Theory and Practice", Carnegie-Rochester Conference Series on Public Policy, 39, pp. 195214.

Taylor J. B. (2000), "Teaching Macro at the Principles Level" American Economic Review, Papers and Proceedings of the American Economic Association, 90, pp. 90-94.

Tobin J. (1956), "The Interest Elasticity of the Transactions Demand for Cash", Review of Economics and Statistics, 38, pp. 241-247.

Tobin J. (1969), "A General Equilibrium Approach to Monetary Theory", Journal of Money Credit and Banking, 1, pp. 15-29.

Tobin J. (1970), "Money and Income: Post Hoc Ergo Propter Hoc?", Quarterly Journal of Economics, 84, pp. 301-317.

Walsh C. E. (2003), Monetary Theory and Policy, Cambridge (Mass.): MIT Press, 2nd. ed.

Wicksell K. (1898), Interest and Prices, London: Macmillan, 1936.

Woodford M. (2003), Interest and Prices, Princeton, Princeton University press.

Wyplosz C. (2006), "European Monetary Union: The Dark Sides of a Major Success", Economic Policy, April, pp. 207-261. 
Elenco dei papers del Dipartimento di Economia

2000.1 A two-sector model of the effects of wage compression on unemployment and industry distribution of employment, by Luigi Bonatti

2000.2 From Kuwait to Kosovo: What have we learned? Reflections on globalization and peace, by Roberto Tamborini

2000.3 Metodo e valutazione in economia. Dall'apriorismo a Friedman, by Matteo Motterlini

2000.4 Under tertiarisation and unemployment. by Maurizio Pugno

2001.1 Growth and Monetary Rules in a Model with Competitive Labor Markets, by Luigi Bonatti.

2001.2 Profit Versus Non-Profit Firms in the Service Sector: an Analysis of the Employment and Welfare Implications, by Luigi Bonatti, Carlo Borzaga and Luigi Mittone.

2001.3 Statistical Economic Approach to Mixed Stock-Flows Dynamic Models in Macroeconomics, by Bernardo Maggi and Giuseppe Espa.

2001.4 The monetary transmission mechanism in Italy: The credit channel and a missing ring, by Riccardo Fiorentini and Roberto Tamborini.

2001.5 Vat evasion: an experimental approach, by Luigi Mittone

2001.6 Decomposability and Modularity of Economic Interactions, by Luigi Marengo, Corrado Pasquali and Marco Valente.

2001.7 Unbalanced Growth and Women's Homework, by Maurizio Pugno

2002.1 The Underground Economy and the Underdevelopment Trap, by Maria Rosaria Carillo and Maurizio Pugno.

2002.2 Interregional Income Redistribution and Convergence in a Model with Perfect Capital Mobility and Unionized Labor Markets, by Luigi Bonatti.

2002.3 Firms' bankruptcy and turnover in a macroeconomy, by Marco Bee, Giuseppe Espa and Roberto Tamborini.

2002.4 One "monetary giant" with many "fiscal dwarfs": the efficiency of macroeconomic stabilization policies in the European Monetary Union, by Roberto Tamborini.

2002.5 The Boom that never was? Latin American Loans in London 18221825, by Giorgio Fodor. 
2002.6 L'economia senza banditore di Axel Leijonhufoud: le 'forze oscure del tempo e dell'ignoranza' e la complessità del coordinamento, by Elisabetta De Antoni.

2002.7 Why is Trade between the European Union and the Transition Economies Vertical?, by Hubert Gabrisch and Maria Luigia Segnana.

2003.1 The service paradox and endogenous economic gorwth, by Maurizio Pugno.

2003.2 Mappe di probabilità di sito archeologico: un passo avanti, di Giuseppe Espa, Roberto Benedetti, Anna De Meo e Salvatore Espa.

(Probability maps of archaeological site location: one step beyond, by Giuseppe Espa, Roberto Benedetti, Anna De Meo and Salvatore Espa).

2003.3 The Long Swings in Economic Understianding, by Axel Leijonhufvud.

2003.4 Dinamica strutturale e occupazione nei servizi, di Giulia Felice.

2003.5 The Desirable Organizational Structure for Evolutionary Firms in Static Landscapes, by Nicolás Garrido.

2003.6 The Financial Markets and Wealth Effects on Consumption An Experimental Analysis, by Matteo Ploner.

2003.7 Essays on Computable Economics, Methodology and the Philosophy of Science, by Kumaraswamy Velupillai.

2003.8 Economics and the Complexity Vision: Chimerical Partners or Elysian Adventurers?, by Kumaraswamy Velupillai.

2003.9 Contratto d'area cooperativo contro il rischio sistemico di produzione in agricoltura, di Luciano Pilati e Vasco Boatto.

2003.10 Il contratto della docenza universitaria. Un problema multi-tasking, di Roberto Tamborini.

2004.1 Razionalità e motivazioni affettive: nuove idee dalla neurobiologia e psichiatria per la teoria economica? di Maurizio Pugno.

(Rationality and affective motivations: new ideas from neurobiology and psychiatry for economic theory? by Maurizio Pugno.

2004.2 The economic consequences of Mr. G. W. Bush's foreign policy. Can th US afford it? by Roberto Tamborini

2004.3 Fighting Poverty as a Worldwide Goal by Rubens Ricupero

2004.4 Commodity Prices and Debt Sustainability by Christopher L. Gilbert and Alexandra Tabova 
2004.5 A Primer on the Tools and Concepts of Computable Economics by K. Vela Velupillai

2004.6 The Unreasonable Ineffectiveness of Mathematics in Economics by Vela K. Velupillai

2004.7 Hicksian Visions and Vignettes on (Non-Linear) Trade Cycle Theories by Vela K. Velupillai

2004.8 Trade, inequality and pro-poor growth: Two perspectives, one message? By Gabriella Berloffa and Maria Luigia Segnana

2004.9 Worker involvement in entrepreneurial nonprofit organizations. Toward a new assessment of workers? Perceived satisfaction and fairness by Carlo Borzaga and Ermanno Tortia.

2004.10 A Social Contract Account for CSR as Extended Model of Corporate Governance (Part I): Rational Bargaining and Justification by Lorenzo Sacconi

2004.11 A Social Contract Account for CSR as Extended Model of Corporate Governance (Part II): Compliance, Reputation and Reciprocity by Lorenzo Sacconi

2004.12 A Fuzzy Logic and Default Reasoning Model of Social Norm and Equilibrium Selection in Games under Unforeseen Contingencies by Lorenzo Sacconi and Stefano Moretti

2004.13 The Constitution of the Not-For-Profit Organisation: Reciprocal Conformity to Morality by Gianluca Grimalda and Lorenzo Sacconi

2005.1 The happiness paradox: a formal explanation from psycho-economics by Maurizio Pugno

2005.2 Euro Bonds: in Search of Financial Spillovers by Stefano Schiavo

2005.3 On Maximum Likelihood Estimation of Operational Loss Distributions by Marco Bee

2005.4 An enclave-led model growth: the structural problem of informality persistence in Latin America by Mario Cimoli, Annalisa Primi and Maurizio Pugno

2005.5 A tree-based approach to forming strata in multipurpose business surveys, Roberto Benedetti, Giuseppe Espa and Giovanni Lafratta.

2005.6 Price Discovery in the Aluminium Market by Isabel FiguerolaFerretti and Christopher L. Gilbert. 
2005.7 How is Futures Trading Affected by the Move to a Computerized Trading System? Lessons from the LIFFE FTSE 100 Contract by Christopher L. Gilbert and Herbert A. Rijken.

2005.8 Can We Link Concessional Debt Service to Commodity Prices? By Christopher L. Gilbert and Alexandra Tabova

2005.9 On the feasibility and desirability of GDP-indexed concessional lending by Alexandra Tabova.

2005.10 Un modello finanziario di breve periodo per il settore statale italiano: l'analisi relativa al contesto pre-unione monetaria by Bernardo Maggi e Giuseppe Espa.

2005.11 Why does money matter? A structural analysis of monetary policy, credit and aggregate supply effects in Italy, Giuliana Passamani and Roberto Tamborini.

2005.12 Conformity and Reciprocity in the "Exclusion Game": an Experimental Investigation by Lorenzo Sacconi and Marco Faillo.

2005.13 The Foundations of Computable General Equilibrium Theory, by K. Vela Velupillai.

2005.14 The Impossibility of an Effective Theory of Policy in a Complex Economy, by K. Vela Velupillai.

2005.15 Morishima's Nonlinear Model of the Cycle: Simplifications and Generalizations, by K. Vela Velupillai.

2005.16 Using and Producing Ideas in Computable Endogenous Growth, by K. Vela Velupillai.

2005.17 From Planning to Mature: on the Determinants of Open Source Take Off by Stefano Comino, Fabio M. Manenti and Maria Laura Parisi.

2005.18 Capabilities, the self, and well-being: a research in psychoeconomics, by Maurizio Pugno.

2005.19 Fiscal and monetary policy, unfortunate events, and the SGP arithmetics. Evidence from a growth-gap model, by Edoardo Gaffeo, Giuliana Passamani and Roberto Tamborini

2005.20 Semiparametric Evidence on the Long-Run Effects of Inflation on Growth, by Andrea Vaona and Stefano Schiavo.

2006.1 On the role of public policies supporting Free/Open Source Software. An European perspective, by Stefano Comino, Fabio M. Manenti and Alessandro Rossi. 
2006.2 Back to Wicksell? In search of the foundations of practical monetary policy, by Roberto Tamborini

2006.3 The uses of the past, by Axel Leijonhufvud

2006.4 Worker Satisfaction and Perceived Fairness: Result of a Survey in Public, and Non-profit Organizations, by Ermanno Tortia

2006.5 Value Chain Analysis and Market Power in Commodity Processing with Application to the Cocoa and Coffee Sectors, by Christopher L. Gilbert

2006.6 Macroeconomic Fluctuations and the Firms' Rate of Growth Distribution: Evidence from UK and US Quoted Companies, by Emiliano Santoro

2006.7 Heterogeneity and Learning in Inflation Expectation Formation: An Empirical Assessment, by Damjan Pfajfar and Emiliano Santoro

2006.8 Good Law \& Economics needs suitable microeconomic models: the case against the application of standard agency models: the case against the application of standard agency models to the professions, by Lorenzo Sacconi

2006.9 Monetary policy through the "credit-cost channel". Italy and Germany, by Giuliana Passamani and Roberto Tamborini

2007.1 The Asymptotic Loss Distribution in a Fat-Tailed Factor Model of Portfolio Credit Risk, by Marco Bee

2007.2 Sraffa?s Mathematical Economics - A Constructive Interpretation, by Kumaraswamy Velupillai

2007.3 Variations on the Theme of Conning in Mathematical Economics, by Kumaraswamy Velupillai

2007.4 Norm Compliance: the Contribution of Behavioral Economics Models, by Marco Faillo and Lorenzo Sacconi

2007.5 A class of spatial econometric methods in the empirical analysis of clusters of firms in the space, by Giuseppe Arbia, Giuseppe Espa e Danny Quah.

2007.6 Rescuing the LM (and the money market) in a modern Macro course, by Roberto Tamborini. 
PUBBLICAZIONE REGISTRATA PRESSO IL TRIBUNALE DI TRENTO 